УДК 371.3, 378.1, 539.3

\author{
Подлєсний С. В., Єрфорт Ю. О., Стадник О. М.
}

\title{
ДИДАКТИЧНІ ТА АКМЕОЛОГІЧНІ АСПЕКТИ РОБОТИ З ТАЛАНОВИТИМИ СТУДЕНТАМИ В РАМКАХ ОЛІМПІАДНОГО РУХУ 3 ТЕОРЕТИЧНОЇ МЕХАНІКИ
}

Більшість передових країн світу йдуть шляхом інтенсивного інноваційного розвитку економіки. Альтернативи інноваційному шляху розвитку України звичайно не існує. Протягом останніх двох десятиліть в програмах всіх урядів нашої країни був передбачений пункт про перехід до інноваційної моделі розвитку. Вчені, інженери, підприємці, представники влади - всі без винятку - за модернізацію економіки, за те, щоб Україна стала високорозвиненою, технологічно просунутою країною. В Указі Президента України «Про Стратегію сталого розвитку «Україна - 2020» зазначено, що: «Україна має стати державою з сильною економікою та з передовими інноваціями».

Необхідність інтенсифікації інноваційних процесів у виробничому секторі економіки зумовлює підвищення вимог до творчої складової праці інженера, його підготованості до конструювання технічних об'єктів і систем, що забезпечують пред'явлені вимоги до їх функціонального призначення. Випускник технічного ВНЗ повинен володіти як високим рівнем творчих компетенцій, що визначають результативність його включення в творчу діяльність взагалі, так і базовими інженерними знаннями, які дозволять йому ефективно вирішувати завдання $з$ проектування нового обладнання і оптимізації його режимних параметрів. Вкрай необачно останнім часом $є$ те, що при проектуванні основних професійних освітніх програм перевага в їх структурі надається вузькоспеціалізованим професійним знанням на шкоду фундаментальним загальноінженерним компетенціям. Володіння на діяльнісному і рефлексивному рівнях підготовки в області математики, фізики, теоретичної механіки дозволять випускнику технічних напрямків не тільки вирішувати нестандартні професійні завдання, але і швидко адаптуватися і до нового виду діяльності, і до нових знань в будь-якій галузі.

Активне застосування нових технологій управління навчальним процесом, зміна структури і змісту освітніх програм і розробка нових методик викладання створюють умови для саморозвитку і самореалізації студента вже в процесі його професійної підготовки.

Творча компетентність спеціаліста, активність його життєвої позиції є інтегральним результатом не стільки змісту освіти, стільки тієї форми, в якій цей процес відбувався [1...4].

З'єднання інноваційних технологій (миследіяльнісних, соціокультурних і психологічних), побудованих на основі рефлексивного методу, пов'язують з основними перспективами і тенденціями розвитку акмеології. Акмеологія розглядає рефлексивні технології як методи формування та вдосконалення професіоналізму і особистісно-професійного зростання. Акмеологічне значення рефлексивної компетентності для професіонала полягає в тому, що здатність до рефлексії і знання іï механізмів дозволяють сформувати власні цінності і принципи, визначити стратегію власного розвитку, спонукають до постійного саморозвитку і творчого ставлення до професійної діяльності. Подібні технології давно стали поширеним явищем освітньої практики. Потрібно створювати умови для саморозвитку і самореалізації студентів вже в процесі бакалаврської підготовки.

Перспективним напрямком розвитку творчих здібностей особистості на сучасному етапі є олімпіадний рух студентів [5...9].

Досліджувана проблема базується на наукових підходах учених філософії професійної освіти (В. П. Андрущенко, В. К. Кремень); підготовки інженерних кадрів (С. Ф. Артюх, 
С. Я. Батишев, В. С. Безрукова, І. Б. Василів, О. Е. Коваленко, Л. З. Тархан, Д. О. Тхоржевский) та інформатизації освіти (I. М. Богданова, М. І. Жалдак, В. М. Монахов, Г. О. Козлакова, Р. С. Гуревич). Питання залучення студентів до творчої роботи і підготовки до участі в олімпіадах розглядалися і закордонними авторами, наприклад, в роботах [10...12].

Протягом десятків років в Донбаській державній машинобудівній академії щорічно проводяться олімпіади з теоретичної механіки (перший етап), а переможці і призери приймають участь у Всеукраїнських олімпіадах (другий етап), що дозволяє узагальнити накопичений досвід в деяких аспектах.

Метою дослідження є розробка комплексу дидактичних і акмеологічних рекомендацій підвищення ефективності роботи з талановитими студентами в курсі теоретичної механіки, зокрема, в рамках олімпіадного руху.

Студентська молодь виконує особливу місію збереження та примноження національнодержавних інтересів своєї країни, історичної та культурної спадщини в цілому сприяє процвітанню і добробуту держави, суспільства, вітчизни. Підтримка молоді, створення умов для прояву і розвитку їх таланту - це одна з ефективних форм інвестицій в розвиток стратегічних ресурсів і національного потенціалу держави.

Система виявлення та розвитку молодих талантів формується на базових принципах, в основі яких $[13,14]$ :

- пріоритет інтересів особистості молодої людини, його право на свободу вибору особистісної індивідуальної траєкторії, професії, безпеки життєдіяльності, здорового способу життя;

- доступність і відкритість;

- індивідуальний підхід в навчанні, безперервність і спадкоємність на всіх рівнях освіти;

- суспільна, професійна, міжвідомча та мережева взаємодія;

- поєднання державних і громадських ініціатив та ресурсів;

- підтримка і стимулювання розвитку талантів протягом усього життя.

У зв'язку з цим дуже нагальним є розвиток процесів ефективної реалізації механізмів студентських олімпіад з метою вдосконалення навчального процесу і досягнення наступних завдань:

- підвищення інтересу студентів до майбутньої професійної діяльності та іiї соціальної значущості, аналізу і проектування своєї освітньої траєкторії;

• розширення спектру компетенцій в рамках освоюваної освітньої програми, розвиток навичок самостійної роботи, творчого мислення;

- контроль і оцінка підготовленості майбутнього фахівця до самостійної професійної та трудової діяльності;

• виявлення талановитої молоді та їх здібностей до системної дії в професійній сфері.

Тому пропонуються напрямки щодо вдосконалення організації та проведення студентських олімпіад, механізми реалізації яких полягають у наступному:

- виявлення та підтримка талановитої молоді;

- забезпечення соціальної доступності участі в олімпіаді для всіх учасників, в тому числі для осіб з обмеженими можливостями здоров'я;

- залучення роботодавців до організації і проведення олімпіад;

- підвищення мотивації і стимулювання молоді до участі в студентських заходах з виявлення талантів;

- розвиток на основі соціального партнерства цільової підтримки талановитої молоді, яка виявила неабиякі здібності в олімпіаді, стимулювання їх до розвитку та вдосконалення лідерських якостей і талантів;

• подальше працевлаштування осіб, які виявили видатні здібності в олімпіаді;

• інформаційний супровід процесів організації та проведення олімпіад;

• проведення більш масштабної інформаційно-рекламної діяльність по популяризації олімпіад серед молоді; 
- розвиток програм, спрямованих на підвищення мотивації та стимулів професорськовикладацького складу ВНЗ до наукової та творчої роботи зі студентами, виявлення і розвитку їх талантів.

Студентські олімпіади мають цілий ряд функцій, які роблять даний вид інтелектуального змагання особливим:

1. Функція перетворення студентів як суб'єктів пізнавальної діяльності та власного розвитку. Включаючись в олімпіадний рух, студенти усвідомлено і з наміром здійснюють свій особистісний вибір, виступаючи в якості суб'єкта соціального становлення направляють свою активність на засвоєння культурних норм і освоєння соціальних ролей, приймаючи відповідальність за максимальну реалізацію особистісного потенціалу.

2. Функція соціалізації, створює умови для формування у студентів активної життєвої позиції.

3. Функція професійної орієнтації, сприяє пропаганді науки і освіти, оскільки олімпіада виявляє найбільш талановитих і підготовлених студентів.

4. Мотиваційна функція, покликана підтримати допитливість, інтерес до науки, дати відчути себе в своєму середовищі, в суспільстві тих, хто також охоплений захопленням, нарешті, отримати заряд впевненості або, навпаки, «збити» зайву зарозумілість, перевірити свої знання, навіть якщо перемога пройшла повз, забезпечуючи настрій на продуктивну пізнавальну діяльність, сприяючи особистісному зростанню.

5. Діалогічна функція. Спільна діяльність в ході студентської олімпіади забезпечує змістовну взаємодію між викладачами та студентами, сприяє передачі і закріпленню соціального досвіду, створює умови для встановлення особистісного контакту і зацікавленого діалогу між представниками різних поколінь.

6. Інноваційна функція. При підготовці до олімпіади викладачі застосовують найпередовіші освітні технології.

Розглянемо деякі підходи до психолого-педагогічної та методичної точок зору до розробки олімпіадних завдань 3 теоретичної механіки, які повинні відповідати певним критеріям:

- не повинно бути тестів (питально-відповідна форма);

- бажано включення завдань, властивих реальним ситуаціям;

- можливе включення завдань 3 недостатньою або надлишковою інформацією;

- студент повинен розуміти, що саме оцінюється в кожному завданні з метою набуття досвіду саморефлексії навчально-пізнавальної діяльності;

- завдання доцільно робити багатоступінчатими;

- слід підвищувати відсоток ситуаційних завдань, аналогічних тим, що використовуються в методиках проблемного навчання.

Доцільно виділити 4 рівня складності олімпіадних завдань:

- репродуктивний (відтворюючий), коли студент успішно вирішує стандартні навчальні завдання в типових ситуаціях (цей рівень завдань не рекомендується використовувати в олімпіадах);

- евристичний, коли студент здатний вирішувати стандартні навчальні завдання в нетипових ситуаціях;

- пошуковий, коли студент успішно вирішує нестандартні задачі в більш-менш типових ситуаціях;

- творчий, коли студент успішно вирішує нестандартні задачі в нетипових ситуаціях.

Аналіз завдань на Всеукраїнських олімпіадах з теоретичної механіки дозволив виділити три рівні складності олімпіадних завдань: базовий (практично не зустрічався), підвищений і високий.

Робота по переходу на компетентнісну модель навчання буде стимулювати викладачів модифікувати форми і методи навчання, а також розробляти нові види конкурсних завдань. 
Після кожного етапу олімпіади студент повинен отримати інформацію про те, якого рівня він досяг за всіма оцінюваними компетенціями, - індивідуальну діаграму рівнів сформованості компетенцій. Такі діаграми будуть давати наочну картину успішності підготовки даного студента, відбивати його здатності і їх динаміку.

Для творчого розвитку студентів необхідний такий зміст освіти, який включає використання системи проблемних завдань, а також допоміжних засобів і неодмінно привчає студентів до рефлексивної діяльності.

Олімпіадні завдання, які також можна назвати нестандартними, зазвичай мають підвищений рівень складності, тобто рівень, необхідний для включення їх в зміст олімпіади і містять в собі навчально-пізнавальні завдання, які не допускають шаблонного рішення і вимагають перетворення вихідного матеріалу. В їхній характеристиці слід мати на увазі: по-перше, наукову новизну для того, хто шукає рішення, а по-друге, підвищені вимоги до інтелекту і наукових знань. Основний зміст, який може стати предметом перетворюючої інтелектуальної та навчально-пізнавальної діяльності при роботі з такими завданнями, - це так званий предметний зміст, або сукупність понять і відносин, істотних для будь-якої наукового знання.

Змоделювати і реалізувати на практиці систему підготовки студентів до олімпіади 3 теоретичної механіки може тільки професійно компетентний викладач. Компетентність викладача висвітлюється:

• в інтелектуальних і вольових здібностях, моральній позиції, професійних установках і мотивах, що визначають творчу активність викладача;

• в професійних знаннях (предметно-наукових, педагогічних, психологічних, дидактичних, загальнокультурних і ін.);

- в професійно-педагогічних навичках і знаннях процесу моделювання та реалізації сучасних підходів в роботі з талановитими студентами, які забезпечують планомірність, прогнозованість і цілісність в роботі з талановитими студентами;

- в своєчасному коригувати прийомів і методів теоретичної та практичної підготовки студентів (рішення олімпіадних завдань різного виду);

- в розумінні необхідності систематично проводити зі студентами заняття з підготовки до участі в олімпіаді;

• в постійній увазі до нових наукових досліджень в цій галузі;

- в конструктивних, гностичних, комунікативних уміннях.

Володіння методикою підготовки студента до участі в олімпіаді $з$ теоретичної механіки передбачає наявність у викладача таких умінь і навичок, як:

1. Визначати розділи теоретичної механіки і вищої математики, які необхідні для виконання конкурсних завдань.

2. Визначати обсяги інформації, якими повинен володіти студент.

3. Складати завдання різноманітного типу для різних етапів олімпіад.

4. Формувати у студента вміння вирішувати конкурсні задачі.

5. Формувати у студента навички самостійної роботи.

Викладачеві, зацікавленому в підготовці студента до участі в олімпіаді, необхідно чітко усвідомлювати, що його відносини зі студентом повинні бути партнерськими. Перевага викладача може виражатися тільки в рівні знань і умінь. Викладачеві необхідно:

- зважати на почуття власної гідності студента;

- розвивати почуття радості, задоволення за самостійно вирішені завдання;

• виховувати у студента прагнення до розвитку наполегливості в досягненні мети;

- використовувати в роботі зі студентом індивідуальний підхід;

- мати почуття міри в обсязі завдань студенту для самостійної роботи.

Регулярна участь в олімпіадах змінює мислення студентів у творчу сторону, що позитивно впливає на успіх не тільки в навчанні, але і в житті. 
Будь-яка діяльність людини відбувається під впливом певних спонукань, які грають роль рушійної сили. Сукупність таких спонукань утворює мотиваційну сферу діяльності. Не $\epsilon$ винятком і навчальна діяльність. В ii мотиваційну сферу входять потреби студента, його інтереси, переконання, ідеали, уявлення про себе, ціннісні орієнтації.

Можна добре спланувати навчальну діяльність, підібрати ефективні завдання, але якщо студенти не зацікавлені, чи не відповідально ставляться до навчального процесу, то результати цієї діяльності будуть невтішні. Саме вміння зацікавити студента своїм предметом перше завдання викладача.

У реальному житті мотиви - соціальні за змістом і походженням. Багато дидактичних категорій (мета, зміст, методи, форми, засоби) нерозривно пов'язані з мотивацією. Найбільш ефективно управляти навчально-виховним процесом можливо через мотивацію.

Навчальна мотивація визначається специфічними для навчальної діяльності факторами: власне освітньою системою, освітнім закладом; організацією навчального процесу; суб'єктивними особливостями студента; суб'єктивними особливостями викладача, перш за все його ставленням до студента, до власної справи; специфікою навчального предмета.

Основні умови створення мотивації до вивчення теоретичної механіки і підготовки до участі в олімпіадах:

- виховання соціальних мотивів, усвідомлення важливості отриманих знань для майбутньої діяльності;

- діяльність, що дає можливість проявити інтелектуальну самостійність, ініціативність;

- створення проблемних ситуацій, доступна складність навчальної діяльності;

- емоційність процесу навчання (важливу роль в цьому відіграє особистість викладача, форми його спілкування зі студентами, під час підготовки до олімпіади викладач повинен грати роль тренера, старшого наставника);

- зміст навчального матеріалу (вдалий підбір завдань з урахуванням виховних, розвиваючих, пізнавальних аспектів).

Навчання відбувається ефективніше при мотивації, орієнтованій на процес і на результат, менш ефективне навчання при мотивації на оцінку, і практично не залежить від орієнтації на «уникнення неприємностей».

У навчальній діяльності мотиви діляться на змістовні та динамічні. Змістовні мотиви це наявність або відсутність сенсу навчання. Саме наявність сенсу навчання виконує спонукальну функцію, висловлює внутрішнє ставлення до навчання. Динамічність мотивів проявляється в емоційності, активності, тривалості процесу навчання.

Пізнавальні інтереси у студентів формуються під впливом емоційних чинників. Вдало підібрані приклади випускників ВН3, які брали участь в олімпіадах з теоретичної механіки, створюють сприятливу емоційну ситуацію. Не менш важливі вдало підібрані для занять завдання, щоб студенти завжди отримували нову інформацію, бачили рівень своїх знань, щоб різниця між незнанням і знанням була завжди зрозуміла і реально досяжна.

Рішення складних, нестандартних завдань олімпіадного рівня потребує творчого підходу, кмітливості, розвиненості креативних здібностей і психологічних механізмів вирішення проблем [12]. Оригінальні олімпіадні задачі можуть вирішувати не всі. Але причина тут не тільки в тому, що у студентів недостатньо розвинений природний інтелект (логіка, кмітливість, уява, гнучкість мислення, інтуїція), але і в тому, що в належній мірі не розроблені і, отже, широко не використовуються в педагогічній практиці методичні прийоми, що враховують креативний потенціал студента і способи вирішення складних, нестандартних завдань.

Для активізації творчого, креативного потенціалу потрібно навчати студентів конкретним прийомам і методам вирішення завдань. Вони повинні розуміти, що слід робити, коли стикаються з невідомим завданням, незвично сформульованою умовою, нестандартною проблемною ситуацією. 
Розглянемо основні психологічні механізми вирішення завдань. У психології виділяють кілька класів розумових механізмів вирішення завдань.

1. Розумовий механізм «випадкового» рішення. Рішення завдання (в тому числі і перенесення способу розв'язання) відбувається випадково на підставі несподіваного збігу якихось елементів завдання з елементами минулого досвіду. Даний механізм включає інтуїцію і може бути корисний для конструювання і відбору загальних прийомів розв'язання складних задач.

2. Телеологічні (цілеспрямовані, або доцільні) розумові механізми. Дані механізми після появи мети підпорядковуються логіці руху до неї. Успішність вирішення завдання залежить від багатства і насиченості асоціативного потоку (має значення кількість і різноманітність виникаючих асоціацій), а також від сформованості і усвідомленості образу майбутнього результату. Мета змушує усвідомити відношення між даними і результатом. Це веде до виділення правильної відповіді. Даний механізм вимагає розвиненості асоціативного мислення, дивергентного, різноспрямованого мислення.

Характеризуючи даний механізм, звернемо увагу на те, що аналіз реалізується переважно через логічне, конвергентне мислення, коли відбувається виділення елементів об'єкта (елементів завдання), його «розчленування» на основі строгих критеріїв, ознак. Операція «синтез» проявляється в асоціативному, багатовимірному, дивергентному мисленні, так як вимагає встановлення різноманітних зв'язків (асоціацій) одного елемента об'єкта (завдання) з іншими. Дані зв'язки і служать основою усвідомлення, виділення найбільш істотних відносин завдання, які визначаються їі метою, що і призводить до шуканого рішення.

Відомий ще один вид телеологічного механізму, який побудований на теорії задачного простору (Г. Саймон і А. Ньюелл). ІІї основні положення:

- завдання представляє собою відмінні поточний й цільовий стани. Обидва стани задані умовами завдання;

- перехід від початкового стану до цільового являє собою процес вирішення завдання. Для завдання може існувати кілька варіантів таких переходів (тобто рішень). Кожний з станів - це репрезентація проблемної ситуації, даної в задачі, на якомусь проміжному етапі рішення. Сукупність можливих станів і носить назву задачного простору;

- перехід між станами здійснюється за допомогою ментальних (розумових) і практичних дій, які пов'язані за своїм змістом з предметною областю завдання.

Існують і інші моделі, які описують психологічні механізми вирішення завдань.

На основі названих психологічних механізмів відбираються або конструюються методи і засоби вирішення складних завдань. Р. Декарта в своїх "Роздумах про метод, щоб вірно спрямовувати свій розум і відшукати істину в науках» радив:

1. Ніколи не приймати за істинне нічого, що б я не визнав таким з очевидністю.

2. Ділити кожну трудність на стільки частин, скільки буде потрібно, щоб краще їі вирішити.

3. Розміщувати свої думки в порядок, починаючи 3 предметів найпростіших і поступово переходити до пізнання складних.

4. Робити якомога більше повні переліки предметів і явищ, щоб бути впевненим, що нічого не втрачено.

Важливим Р. Декарт вважав і наочне зображення фігур, об'єктів завдання.

Дійсно, рішення складного та незрозумілого завдання слід починати зі складання елементів завдання, понять і формул, закономірностей і законів, що мають відношення до умови завдання. Все це необхідно представити в наочному вигляді. Звідси випливає ідея використовувати понятійний кластер як допоміжний засіб вирішення завдання. Метою складання кластера є актуалізація знань студента (на основі асоціативного, дивергентного мислення) навколо ключового елемента завдання (поняття, фізичної величини, закону і т. ін.). Студент тимчасово відходить від завдання і намагається в наочній формі зафіксувати свій досвід і знання, необхідні для вирішення. І студенту найчастіше вдається знаходити, визначити, зафіксувати в ньому необхідні для вирішення елементи, які відтворюються в асоціативному, креативному потоці мислення. Але це ще не означає, що знайдено рішення. Завдання буде 
вирішене, коли студент усвідомлює значущі відносини між його елементами, побачить зв'язки між шуканими і вихідними даними. I тепер потрібно знову повернутися до аналізу умови задачі. Понятійний кластер допомагає висвітлити приховані елементи завдання, а логіка і досвід дозволяють знайти потрібні відносини і оформити їх у вигляді рішення.

Наступний - метод редукції завдання. Суть редукції полягає в спрощенні умови задачі, зведенні ії до відомої задачі (або типу задач), рішення якої студенту відомо або не викликає ускладнень. Редукція завдання - це творчий процес. Потрібно побачити в різних варіантах зміни умови задачі значущі зв'язки та елементи, співвіднести їх 3 проблемним, найбільш «важким» елементом. Спрощуючи завдання, роблячи його більш зрозумілим для себе, студент відмовляється від самого «важкого» для нього елемента, який здається непереборною перешкодою на шляху його вирішення. Після того як актуалізовані способи вирішення більш простих завдань, потрібно повернути в умову задачі його «важкий» елемент і відповісти на питання а що він змінює в рішенні, що може додати до пояснення умови? Повторне занурення в умову складного завдання, в його аналіз тепер уже відбувається в актуалізованому полі інформації, необхідної для вирішення. Встановлення та усвідомлення значущих зв'язків між елементами завдання на основі асоціативно-логічного (телеологічного) і резонансного механізмів мислення в поле актуалізованої інформації буде проходити більш ефективно і продуктивно.

Так само є метод перехідних станів завдання. Заснований він на теорії задачного простору і відповідного йому психологічного механізму. Вибір методу визначається особливостями процесу рішення складного завдання.

Для студентів, що не мають досвіду вирішення складних, олімпіадних завдань, утруднене цілісне сприйняття ключових відносин, параметрів і елементів завдання. Важко зрозуміти, як одні елементи завдання пов'язані з іншими. Завдання розпадається на, здавалося б, не взаємозалежні фрагменти. Студенту важко побачити загальну логіку вирішення такого завдання. Саме тоді рекомендується скористатися методом перехідних станів завдання. Відповідно до цього методу слід знайти ті невідомі величини, додаткові або допоміжні параметри, пошук яких не викликає особливих труднощів. Якщо це зробити, завдання набуває додаткові дані, його умови розширюється. Завдання переходить в новий (один з проміжних) стан. Цінність його в тому, що нові знайдені елементи можуть підштовхнути студента до нових ідей, навести на певну логіку рішення, відповідну меті завдання.

При вирішенні складного завдання можна використовувати відразу кілька методів.

Можна дати загальні рекомендації щодо застосування креативних методів, відштовхуючись від тих можливих труднощів, які студенти можуть відчувати, вирішуючи завдання.

1. Вирішуючи складну задачу, потрібно спочатку звернути увагу на можливість іiі редукції. Якщо студент, спрощуючи умову задачі, обходячи ту чи іншу іiі «трудність», побачить в цьому спрощеному варіанті знайомий тип завдання, згадає той чи інший спосіб їі вирішення, то він може обійтися і без інших креативних методів.

2. Якщо редукція не допомагає, завдання не вдається спростити, звести до відомого типу завдань, то корисно спочатку скласти понятійний кластер для ключового елемента завдання (найчастіше для шуканого). Кластер допоможе розширити інформаційне поле завдання, включити в активну увагу студента всю необхідну сукупність зв'язків і відносин завдання. I це, звичайно, може допомогти у визначенні логіки рішення задачі, вибудовуванні логічної лінії від відомих даних завдання до його шуканого.

3. Якщо і складання кластера не допомогло подолати труднощі завдання, це означає, що для студента завдання «розпалося» на окремі фрагменти, зв'язки між якими він не бачить. В цьому випадку і буде корисний метод перехідних станів. Вирішуючи завдання, потрібно спробувати знайти ті його елементи (проміжні невідомі), пошук яких не викликає особливих труднощів. Потім варто спробувати співвіднести знайдені проміжні величини з шуканим задачі. Цілком можливо, що на якомусь проміжному етапі рішення студент побачить приховані зв'язки (або зв'язок), елементи, необхідні для остаточного вирішення. Використовуючи метод 
перехідних станів, в принципі, завдання вирішити можна, але не завжди вдається зробити це раціональним способом. Тому корисним буває вже після знайденого рішення ще раз проаналізувати всі проміжні стани завдання (етапи рішення). Це може допомогти знайти більш раціональний шлях вирішення, більш витончену ідею і спосіб вирішення, які потрібно обов'язково запам'ятати, щоб в майбутньому зуміти побачити ці ідеї і способи в інших, структурно схожих складних завданнях. I тоді більш тривалий і копіткий метод перехідних станів може бути замінений методом редукції.

Не можна виключити, що жоден з перерахованих креативних методів не допоможе студенту вирішити задачу. Справа в тому, що дані методи є додатковими до основних предметно-специфічних методів вирішення завдань з теоретичної механіки. Пропонуючи студентам вирішувати складні завдання, потрібно виходити з того, що вони якісно освоїли відповідні предметно-специфічні методи, знайомі з основними типами задач по темі, що вивчається, освоїли теоретичний матеріал, іншими словами, мають певну підготовку. Тоді вони можуть ставити перед собою більш високі цілі - вийти на рівень складних, олімпіадних завдань. I навіть якщо студент все ж не впорався зі складним завданням, намагаючись вирішити його різними методами, - це все одно дуже корисна для нього робота: відбувається придбання необхідного досвіду, виявляються слабкі місця його теоретичної підготовки або недостатність сформованості тих чи інших навичок, що в сукупності вкаже шлях подальшого вдосконалення знань і досвіду студента $з$ навчального предмета.

3 метою методичної підтримки системи підготовки студентів до участі в олімпіадах 3 теоретичної механіки авторами було видано два навчальних посібника з розв'язання задач підвищеної складності по розділах «Статика» $\mathrm{i}$ «Динаміка» і підготовлений до видання третій посібник з кінематики. Навчальні посібники дозволяють активізувати зацікавленість студентів у вивченні законів і закономірностей, які описують механічну взаємодію і рух матеріальних тіл, розвинути в них уміння правильно формулювати і розуміти основи фундаментальних законів механіки, будувати логічно стрункі алгоритми використання знань 3 теоретичної механіки.

У запропонованих навчальних посібниках наведені методичні вказівки і приклади розв'язання задач підвищеної складності з зазначених розділів.

Розв'язок задач наведено на прикладах виконання, у яких застосовуються різноманітні прийоми. Показано, що одна і та ж задача може бути виконана різними методами, які можуть значно відрізнятися за складністю залежно від вибору теореми, рівняння або принципу, що дозволяє вибрати найбільш раціональний у конкретному випадку.

Розділи навчальних посібників закінчуються задачами для самостійної роботи, що дає змогу визначити знання студентів і їх вміння розв'язувати різноманітні задачі класичної механіки. У розділі відповідей задач самостійної роботи наведена значна кількість вказівок до їх розв'язання.

Можна запропонувати наступні критерії оцінки конкурсних завдань. Рішення кожного завдання оцінюється викладачем за 100-бальною шкалою (Табл. 1).

Залежно від складності завдань можуть використовуватися вагові коефіцієнти, сума яких повинна дорівнювати 1.

Авторами розроблена методика селекції студентів, з якими буде продовжена робота з підготовки до участі в олімпіадах:

• вхідний контроль знань, виконання завдань з теоретичної механіки при проходженні комп'ютерної практики;

- індивідуальний підхід в навчанні: складання графіку занять, рекомендація типових задач, закріплення викладачів-консультантів, залучення до участі у конференціях та наукової роботи;

- стимулювання до участі у внутрішньому конкурсі: додаткові бали до підсумкової оцінки знань з теоретичної механіки, перспективи науково-дослідного співробітництва;

- остаточне призначення переможця та подальша робота з ним. 
Критерії оцінки конкурсних завдань

Таблиця 1

\begin{tabular}{|c|l|c|c|}
\hline $\begin{array}{c}\text { № } \\
\text { 3/п }\end{array}$ & \multicolumn{1}{|c|}{ Критерії оцінок конкурсних завдань } & Бал \\
\hline 1 & $\begin{array}{l}\text { Завдання правильно вирішене, добре оформлене і рішення досить } \\
\text { аргументовано }\end{array}$ & $90-100$ \\
\hline 2 & $\begin{array}{l}\text { Хід рішення і результат вірні, але робота погано оформлена або (i) рішення } \\
\text { недостатньо аргументовано }\end{array}$ & $80-89$ \\
\hline 3 & $\begin{array}{l}\text { Рішення принципово правильне, але результат є помилковим через } \\
\text { допущені арифметичні помилки }\end{array}$ & $70-79$ \\
\hline 4 & $\begin{array}{l}\text { Хід рішення вірний, але результат є помилковим з огляду на те, що } \\
\text { допущені несуттєві помилки в запису формул }\end{array}$ & $60-69$ \\
\hline 5 & Ідея і хід розв'язання задачі вірні, але рішення не доведено до кінця & $50-59$ \\
\hline 6 & Поряд з правильними ідеями рішення містить і деякі неправильні положення & $40-49$ \\
\hline 7 & Поряд з правильними положеннями рішення містить і принципово невірні & $30-39$ \\
\hline 8 & $\begin{array}{l}\text { Рішення доведено до кінця, але засноване на принципово невірних } \\
\text { передумовах }\end{array}$ & $20-29$ \\
\hline 9 & $\begin{array}{l}\text { Рішення не доведено до кінця і засноване на принципово невірних } \\
\text { передумовах }\end{array}$ & $10-19$ \\
\hline 10 & $\begin{array}{l}\text { Рішення немає, але наведені деякі неясні положення, які можна розглядати } \\
\text { якспробу вирішення завдання }\end{array}$ & $1-9$ \\
\hline 11 & Рішення немає & 0 \\
\hline
\end{tabular}

До участі у наступному етапі залучаються, як правило, два студенти. Перший - це переможець поточного (другого) року навчання. 3 ним проведена скорочена програма підготовки. Другий - це переможець попереднього (третього) року навчання. У нього $є$ досвід, він прослухав курс механіки у повному обсязі, а також курси вільного вибору: «математичне моделювання механічних систем» та «коливання механічної системи 3 двома ступенями вільності», з ним проведена робота по написанню наукових статей та методичних розробок.

Узагальнений досвід цієї роботи втілено в наказах ДДМА про роботу з обдарованою молоддю, при нарахуванні рейтингу студента та рекомендації щодо його подальшого працевлаштування.

Більшість $з$ них здобули магістерську освіту, отримали науковий ступінь кандидата наук, а деякі ступінь доктора наук (Шеремет О. - завідуючий кафедрою). Випускники затребувані провідними підприємствами нашого міста, області, України та за кордоном (Казаков С., Семенов В. - у США, Лаптєва О. - Німеччина, Сатонін В. - Італія та ін.).

За період з 1997 року по 2012 рік учасники всеукраїнських олімпіад здобули два перших (Казаков С, Гомора Д.), три (Казаков С., Шишкін А. - два рази) других та шість (Медвєдєв В., Ткаченко Б, Локтіонов Ю.) третіх призових місць та стабільно входили щорічно до десяти найкращих переможців цих змагань.

\section{ВИСНОВКИ}

Виявлення талановитих студентів і цілеспрямована робота з ними з підготовки та участі в студентських олімпіадах 3 теоретичної механіки є одним 3 елементів в системі підготовки висококваліфікованих фахівців з розвиненими творчими компетенціями, що особливо затребуване роботодавцями в сучасних умовах розвитку інноваційної економіки.

Ефективність реалізації механізмів студентських олімпіад з метою вдосконалення навчального процесу можна поліпшити, спираючись на базові принципи і рекомендації, викладені в статті. 
Підходи до розробки олімпіадних завдань з теоретичної механіки повинні відповідати певним психолого-педагогічним та методичним критеріям.

Ефективно розвивати творчі здібності студентів в системі підготовки до участі їх в олімпіадах 3 теоретичної механіки може тільки зацікавлений і професійно компетентний викладач, який володіє певними уміннями і навичками, здатний мотивувати студента. Правильно вибудовані навчальні, соціальні, емоційні, змістовні та динамічні мотиви, відповідальне ставлення студента до навчального процесу є запорукою очікуваного результату.

Розглянуті механізми, прийоми і методи розв'язання складних креативних задач, а також розроблені авторами статті посібники з розв'язання задач підвищеної складності з теоретичної механіки мають стати методичною підтримкою в системі підготовки студентів до участі в олімпіадах.

Перспективи подальших досліджень у даному напрямі автори вбачають в розробці дидактичних аспектів роботи з талановитими студентами в рамках нових форм олімпіадного руху, які починають ширше використовуватись останнім часом: дистанційних, командних, евристичних, міждисциплінарних (міжпредметних) та ін.

\section{СПИСОК ВИКОРИСТАНОЇ ЛІТЕРАТУРИ}

1. Наказ Міністерства освіти і науки, молоді та спорту України від 13.12.2012 №1410 "Про затвердження Положення про проведення Всеукраӥнської студентської олімпіади", зареєстрований в Міністерстві юстииї Украӥни 27 грудня 2012 року за № 2207/22519 [Електронний ресурс]. - Режим доступу: https://zakon.rada.gov.ua/laws/show/z2207-12.

2. Колотило М. О. Творчість як засадничий ресурс навчання студентів у сучасному університеті / М. О. Колотило // Вісник Національного технічного університету Украӥни "Київький політехнічний інстиmут". Філософія. Психологія. Педагогіка. - 2011. - № 2. - С. 68-72.

3. Белова Ю. Ю. Модель професійної компетентності майбутнього інженера машинобудівної галузі: [Електронний ресурс] / Ю. Ю. Белова. - Режим доступy: http://bdpu.org/sites/bdpu.org/files/konferencii/pednau/n2/ukr/2.pdf.

4. Прядко Ю. Г. Об опьте работы с одаренными студентами / Ю. Г. Прядко, С. В. Слепова // Междунар. журн. приклад.и фундамент. исслед. - 2013. - № 10. - С. 289-291.

5. О повышении эффективности всероссийских студенческих олимпиад / Кошкин В. И., Гордеев А. И., Белоиерковский А. В. и др. // Высшее образование в России. - 2014. - № 11. - C. 25-30.

6. Миндеева С. В. Олимпиадное движение как форма активизации учебно-познавательной деятельности студентов / С. В. Миндеева, О. Д. Толстых // Международный информационно-аналитический журнал «CredeExperto: транспорт, общество, образование, язык». - Декабрь 2016. - № 4(11). - С. 1-9.

7. Попов А. И. Олимпиадное движение студентов как форма организации творческой самостоятельной работь в вузе / А. И. Попов // Инновации в образовании. Вестник Нижегородского университета им. Н. И. Лобачевского. - 2013. - № 5 (2). - С. 166-170.

8. Попов А. И. Непрерывное творческое саморазвитие студентов в олимпиадном движении / А. И. Попов // Научно-педагогическоеобозрение. - 2014. - № 3 (5). - С. 58-63.

9. Попов А. И. Механизм сопровождения творческого развития студентов в олимпиадном движении по теоретической механике / А. И. Попов, Г. И. Дубровина // Ученые записки. Электронный научный журнал Курского государственного университета. - 2016. - № 2 (38). - Режим достуny: http://scientific-notes.ru/pdf/043-015.pdf.

10. Cheng $W, W u X$, Zhang Z, et al. Effective project-oriented approach for training professional mechanical engineers in undergraduate education. International Journal of Mechanical Engineering Education 2013; 41: $289-296$.

11. Tolbert DA and Daly SR. First-year engineering student perceptions of creative opportunities in design. International Journal of Engineering Education 2013; 29: 879-890.

12. Weinstein RD, O'Brien J, Char E, et al. A multidisciplinary, hands-on, freshman engineering team design project and competition. International Journal of Engineering Education 2006; 22: 1023-1030.

13. Окушко Н. Б. Развитие креативного мышления студентов в процессе решения задач повышенной сложности в курсе общей физики / Н. Б. Окушко, Т. В. Лавряшина, Д. С. Вершинин // Вестник Кузбасского технич. универ. - 2011. - №.4. - C. 128-131.

14. Положення про проведення Всеукраӥнської студентської олімпіади [Електронний ресурс]. - Режим docmyny: https://zakon.rada.gov.ua/laws/show/z2207-12. 